\title{
RADY EWANGELICZNE WEDŁUG DOKTORÓW KARMELU
}

Na samym początku wypada zapytać: czy jest sens opracowywać powyższy temat w oparciu o nauczanie autorów sprzed czterystu lat, wiedząc, jak wielkiej zmianie uległa teologia rad ewangelicznych po Soborze Watykańskim II? Wcześniej powołanie zakonne wiązane było $z$ cnota religii, a w kwestii rad kładziono akcent głównie na ślub składany Bogu i wynikajace $z$ niego konsekwencje prawne oraz moralne. Mieliśmy do czynienia z przewaga prawa kanonicznego nad teologią, ascetyki nad mistyką, teologii moralnej nad duchowością ${ }^{1}$. Po Soborze zmienił się kontekst postrzegania życia konsekrowanego. Ze stanu, w którym należało osiągać własną doskonałość na podstawie ślubu, stało się ono życiem Kościoła i jego wyjątkowym wyrazem, który najpierw wierzacym, a potem całemu światu ma ukazywać realizację Dobrej Nowiny. Ze sprawy niemal prywatnej stało się czynnikiem ewangelizacyjnym w Kościele i dla Kościoła.

Nie odpowiemy na naszą wątpliwość, zanim nie zgłębimy myśli na temat ślubowanych rad ewangelicznych u doktorów Karmelu, w szczególności u św. Teresy od Jezusa i św. Jana od Krzyża.

Struktura tej refleksji jest w zasadzie prosta. Po ogólnym spojrzeniu na rady ewangeliczne u świętych doktorów Karmelu przejdziemy do bardziej szczegółowego omówienia każdej z nich.

1 Por. S.M. Alonso, Consejos evangelicos, w: Diccionario Teologico de la Vida Consacrada, Madrid 1989, s. 422. 


\section{RADY EWANGELICZNE u DOKTORÓW KaRMELU W OGÓLNOŚCI}

Szczegółowe studium terezjańskiej doktryny potwierdza nasze założenia. W myśli Teresy od Jezusa na temat rad ewangelicznych znajdziemy odbicie nauczania teologicznego jej epoki ${ }^{2}$. Jeśli chodzi o użyte słownictwo, sprawa wygląda następująco: to wyrażenie pojawi się w całości tylko jeden raz, na początku Drogi doskonatości, gdy Święta wyjaśnia cel założenia pierwszego klasztoru karmelitanek bosych. Wobec zła, jakie stało się w Kościele w wyniku reformacji luterańskiej, ona pragnie w sposób radykalny wypełnić rady ewangeliczne i pomóc uczynić to samo małej wspólnocie zgromadzonej wokół niej (D 1,2). Trzy razy pojawi się wyrażenie „rady Chrystusa”, jeden raz użyje określenia „przykazania

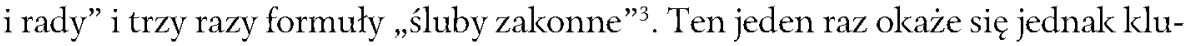
czem do całej jej nauki o radach ewangelicznych. Właśnie jej osobiste życie, jej egzystencjalny ideał staje się światłem dla wszystkich tematów szczegółowych. Co postanowiła u początku dzieła fundacyjnego, tym żyła przez resztę życia. Wystarczy zauważyć, że w momencie pierwszej fundacji w 1562 roku mija osiem lat od jej mistycznego nawrócenia, które zanurzyło ją całkowicie w misterium Chrystusa, do tego stopnia, że od tego momentu nie było to już jej życie, ale życie Boga $w$ niej $(\dot{Z} 23,1)$. Nie koncentruje się w związku z tym na zobowiązaniach moralnych jako na czymś najważniejszym, ale na osobowej relacji z Bogiem. Jeżeli porusza wiele spraw dyscyplinarnych i organizacyjnych, to zawsze w perspektywie powołania i misji w Kościele.

Podobna sytuacja jest u św. Jana od Krzyża. Swoje powołanie zakonne przeżył, w całej pełni realizując swój jedyny życiowy ideał: zjednoczenie z Bogiem, które też stanie się samym centrum jego nauczania. Przeżył je, pragnąc jak najdoskonalej upodobnić się do Chrystusa, co też wyraził w jednym z listów, mówiąc, że życie, ,jeżeli nie jest naśladowaniem Go, nie jest dobre”. Gdzie Jan od Krzyża pisze o życiu zakonnym? Zwylk zadawano odwrotne pytanie: czy to, co pisze, odnosi się do osób świeckich? ${ }^{5}$ Zobaczmy dedykacje poszczególnych dzieł. Droge na Górę Karmel pisze dla niektórych karmelitów i karmelitanek bosych, którzy go o to prosili (DGK, Prolog 9); Przestrogi do pewnego zakonnika - tytuł mówi sam za siebie; Stowa światta i mitości dał mniszce z Beas; Pieśn duchowa pisze dla Anny od Jezusa (Lobery) i dla całego Karmelu; Listy, oprócz siedmiu, skierowane są do karmelitanek i karmelitów. Żywy płomień mitości dedykowany jest oczywiście osobie świeckiej. Z treści jego dzieł wynika, że to nauczanie dotyczy ogólnego

2 Por. F. Malax, Consejos evangelicos, w: Diccionario de Santa Teresa. Doctrina e Historia, red. T. Alvarez, Burgos $2006^{2}$, s. 160.

Por tamże

List 25 z 6 lipca 1591, w: Św. Jan od Krzyża, Dzieła, Kraków 19955 s. 835.

Por. J.V. Rodríguez, San Juan de la Cruz profeta enamorado de Dios y maestro, Madrid 1987, s. 371 . 
powołania do świętości - o czym też świadczy przyznany mu tytuł doktora Kościoła powszechnego.

W takim układzie całą jego doktrynę należy umieścić w samym sercu życia zakonnego. Podobnie zresztą można by postąpić z pozostałymi stanami życia w Kościele. Centrum procesu zjednoczenia i oczyszczenia (uświęcenia) stanowi ze strony człowieka postawa teologalna, omówiona w drugiej i trzeciej księdze Drogi na Górę Karmel. Wiara stanowi jedyny proporcjonalny środek zjednoczenia z Bogiem, ta z kolei w logice zbawienia występuje razem $z$ nadzieją i miłością. Wiara, będąc otwartością na misterium Boga i Jego zbawienia, w życiu zakonnym automatycznie staje się drogą przeżywania posłuszeństwa; nadzieja, która oczyszcza pamięć z przywiązania do wszelkiego rodzaju dóbr materialnych i duchowych, będzie przeżywana w logice zakonnego ubóstwa; wreszcie miłość stanie się formą relacji z Bogiem traktowanym jako wyłączny Oblubieniec. W naszych dalszych rozważaniach przyjmiemy taką właśnie perspektywę rad ewangelicznych, podyktowaną centralnym miejscem cnót teologalnych i ich kolejnością ${ }^{6}$.

\section{RADY EWANGELICZNE SZCZEGÓ£OWO}

\subsection{Posłuszeństwo}

Teresa od Jezusa pisze o radach ewangelicznych w kontekście powołania chrześcijańskiego i karmelitańskiego, którego celem jest świętość lub doskonałe zjednoczenie z Bogiem, co wyraża się w pełnej zgodności naszej woli z wolą Bożą:

Bo na czym polega najwyższa doskonałość? Nie polega ona na pociechach wewnętrznych ani na tym, by kto miewał wielkie zachwycenia, widzenia i ducha proroctwa, tylko na tym, by wola nasza tak była zgodna $z$ wolą Boga, iżby nie było takiej rzeczy, której Bóg chce, a my byśmy jej nie chcieli całą wolą naszą, i równie ochotnie przyjmowali rzeczy gorzkie, jak i rzeczy przyjemne, wiedząc, że taka jest Jego wola (F 5, 10).

Posłuszeństwo jest zaś najszybszą drogą prowadzącą do tego celu (F 5, 11). Prawdziwie miłujący Boga nie zważa na własną wygodę, ale na to, jak najlepiej wypełnić wolę Pana (F 5, 5). W pismach Teresy znajdziemy treści dotyczące posłuszeństwa, jakim żyła ona sama, roli posłuszeństwa na drodze modlitwy czy wreszcie osób posłusznych?

6 O przyporządkowaniu cnót teologalnych radom ewangelicznym zob. JW. GogolA, Rady ewangeliczne. Teologia, praktyka, formacja, Kraków 2003², s. 20-27.

7 Por. F. Malax, Consejos evangelicos, s. 160-161. 
Nie powinno dziwić, że u św. Teresy posłuszeństwo wiąże się ściśle z wolą Bożą i z drogą świętości (D 18, 7; 39, 3). Konkretne wskazania w jej pismach często odnoszą się do posłuszeństwa przełożonym, spowiednikom lub teologom. Powie na przykład, że bez niego życie zakonne nie jest nic warte (D 18,7), a osoba, która nie chce wypełnić tego ślubu z całą doskonałością, nie wiadomo po co przyszła do klasztoru (D 18,8). Będzie też mówić o dobrach, jakie wynikają z praktyki posłuszeństwa, a są to pokora, pewność, że się nie błądzi w drodze do nieba, pokój ducha, panowanie nad sobą (F, Prolog; 4, 2; Ż 19,4).

W jej życiu dobrodziejstwo posłuszeństwa ujawnia się szczególnie w kontekście życia mistycznego oraz dzieła założycielskiego. Wybuch nadzwyczajnych zjawisk mistycznych wzbudził u Teresy lęk: najpierw by nie być oszukaną przez szatana, a potem przed inkwizycją. W tej sytuacji udaje się do osób pobożnych i uczonych, jak to podpowiedział jej sam Pan (Ż 23, 3.18; 26, 5; 28, 15). Jest przekonana o tym, że to droga obowiązkowa dla wszystkich ludzi modlitwy, także niezwiązanych ślubem posłuszeństwa (D 18,8). To posłuszeństwo stało się dla niej nadzwyczaj trudne, gdy nakazano jej zaprzestanie modlitwy, a więc myślenia o Bogu i okazywania Mu swojej miłości (Z 29,7). Zdarzyło się nawet, że spowiednik kazał pokazać figę, gdy pojawi się wizja mistyczna $(\dot{Z} 25,22 ; 29,6)$.

$W$ dziele fundacyjnym potrafi połączyć własną wizję z posłuszeństwem uczonym $(\dot{Z} 34,1 ; 35,7 ; 36,5)$. Z posłuszeństwa powstaną wszystkie ważne dzieła pisane: Księga życia (Ż 19, 4), Twierdza wewnętrzna (T I, 1, 1; III, 1, 3), Księga fundacji (F 27, 22). Droge doskonatości pisze z posłuszeństwa swoim siostrom z pierwszej fundacji św. Józefa w Awili (D 1, 1; 42, 7).

Sprawdzianem modlitwy jest postawa posłuszeństwa wobec przełożonych (D 18, 7). W kontekście nadzwyczajnych wizji Teresa stwierdzi, że przeorysza powinna bardziej cenić te siostry, które idą drogą pokory i posłuszeństwa, niż te, które otrzymują nadzwyczajne wizje. Jeżeli pochodzą one od Boga, to drobne upokorzenie im nie zaszkodzi, a inne tym większą będą mieć radość z posłuszeństwa i pokory $(F 8,9)$. Posłuszeństwo bardzo sprzyja modlitwie także w przypadku osób świeckich, więc i one nie powinny pozostawać same i być narażone na pełnienie własnej woli (T III, 2, 12). Przypomni w tym kontekście, że Bóg bardziej pragnie posłuszeństwa niż ofiary (F 5, 13; 6, 22). Na drodze modlitwy prym wiodą miłość i posłuszeństwo. Na taką postawę człowieka odpowiada miłością Umiłowany (D 34, 10; T IV , 3, 13; F 5, 3).

Tę naukę Swięta zobrazuje przykładami. Pierwszym posłusznym jest Jezus, który z posłuszeństwa stał się naszym sługą ( $F 5,17)$, potem wskaże na inne pobożne dusze, które dzięki posłuszeństwu postąpiły w modlitwie, nawet nie mając na nią czasu, jak pewien zakonnik (F 5, 7), czy wreszcie na siostry z własnych wspólnot (F 1, 3-historia z ogórkiem, F 1, 4- historia o studni ze złą wodą). 
We wszystkich miejscach, gdzie św. Teresa wspomina o posłuszeństwie, mówi o nim jako o czymś oczywistym, nie wyjaśniając, co dokładnie ma na myśli. Inni też nie pytają, bo wiedzą, o co chodzi. Jak zatem je rozumie? Z przytoczonych przykładów wynika, że chodzi jej po prostu o posłuszeństwo ludziom, którzy mają nad nami władzą z racji profesji lub też z racji ekonomii sakramentalnej Kościoła. Z całej nauki Świętej wynika jednak, że posłuszeństwo ma zawsze charakter nadprzyrodzony i nigdy nie oznacza jedynie odpowiedniego stosunku do przełożonych. Bez jego nadprzyrodzonego charakteru stałoby się jedynie upokarzającą dyscypliną o wątpliwej wartości społecznej.

Bardzo podobną naukę znajdujemy u św. Jana od Krzyża. Dla niego zakonnik jest kimś, kto całe życie i działalność poświęcił Bogu (Rady dla zakonnika, nr 8); „czynności bowiem zakonnika nie są jego własnością, lecz rządzi nimi posłuszeństwo" (Przestrogi, nr 11). Powtórzy też biblijne twierdzenie, że Bogu milsze jest posłuszeństwo od ofiary (por. $1 \mathrm{Krl}$ 15, 22; Przestrogi nr 11). Nie znajdziemy u niego współczesnego podejścia do tej problematyki, jak dialog z przełożonymi, rozeznanie wspólnotowe Bożej woli czy obiekcja sumienia. Obowiązuje tzw. ślepe posłuszeństwo.

\subsection{Ubóstwo}

Materialny aspekt ubóstwa jest $\mathbf{u}$ doktorów Karmelu czymś podstawowym i oczywistym. Kiedy pada to słowo, bez żadnych dopowiedzeń wiadomo, że chodzi o ubóstwo materialne.

Zdecydowaną obronę ubóstwa św. Teresa podejmie na początku Drogi doskonałości, gdzie nawiąże do św. Klary, podzielając jej poglądy, że wysokie są mury obronne ubóstwa (D 2, 8; D 2, 3.7; Ż 33, 13), i będzie się zachwycać jego wielkością, na przykład:

Ubóstwo jest to dobro, które zawiera w sobie wszystkie dobra świata; jest to wysokie panowanie. Jest to, powtarzam, panowanie nad wszystkimi dobrami tego świata, bo kto nie dba o nie i nimi gardzi, ten wyższy jest nad nie i panuje nad nimi (D 2, 5).

O ubóstwie materialnym jest mowa zwłaszcza przy okazji zakładania nowych domów. Przy pierwszej fundacji pojawia się ideał całkowitego ubóstwa bez żadnych dochodów. Teresa dowiaduje się bowiem, że mnisi z Góry Karmel żyli w taki sposób, nie robiąc nawet zapasów na dzień następny, i chce ich naśladować. Będzie zabiegać, by jej mniszki żyły z pracy rạk własnych (Ż 35, 2-6; Ż 36, 15; Ż 10, 7) i $z$ jałmużny. Potem pójdzie na pewien kompromis: w dużych miejscowościach zaprowadzi całkowite ubóstwo, w mniejszych postara się o stałe utrzymanie dla 
sióstr ( F 9, 3; 24, 17). Ubóstwo ducha natomiast przebija z licznych jej tekstów, ale trudno znaleźć takie, które by je opisywały (np. Ż 11,7-17).

Dlatego najbardziej reprezentatywną naukę w tym względzie znajdziemy u św. Jana od Krzyża. Nacisk na ubóstwo duchowe jest u niego tak wiellki, że całą jego naukę o drodze do zjednoczenia z Bogiem sprowadza się czasami do określenia nada - „nic”. Oznacza ono nie tyle brak rzeczy materialnych, ile odpowiednia relację duchową $z$ wszelkim stworzeniem - relację pełnej wolności i braku egoistycznego przywiązania do jakiegokolwiek dobra tak z porządku materialnego, jak i duchowego. Dotyczy to nawet dóbr nadprzyrodzonych. Odpowiednie terminy na określenie tej rzeczywistości to „duchowe ogołocenie” - desnudez, „oczyszczenie”- purificación, „wyrzeczenie”- dasasimiento, „pustka i ubóstwo ducha” - vacio y pobreza de espiritu'. Zauważmy przy okazji, że termin „oczyszczenie” dotyczy jednocześnie i przede wszystkim czystości miłości - ponieważ to miłość wiąże nas z różnymi przedmiotami miłości. Zatem ta reflelksja dotycząca duchowego ubóstwa w jednakowym stopniu odnosi się do czystości. W tym wypadku nie chodzi oczywiście o składany ślub czystości, ale o ideał, do którego powinna zmierzać miłość wszystkich wierzących. Już te terminy wskazują na to, że znajdujemy się w samym sercu mistycznej doktryny św. Jana od Krzyża. On nie wydaje się przesadnie skoncentrowany na ubóstwie materialnym. Przyjął styl życia panujący w Karmelu w tamtym czasie. Z opisów historycznych wynika, że ubóstwo było wówczas duże. Jednak w swoich pismach Święty nie koncentruje się na dyscyplinie stanu posiadania materialnego, ale na dynamice osiagania zjednoczenia przemieniającego $z$ Bogiem przez miłość. W tej kwestii mamy dwojakiego rodzaju działania: niejako oddolne, czyli od człowieka do Boga, i odgórne - od Boga do człowieka. Oczywiście idą one w parze, ale pierwszy aspekt, z punktu widzenia doświadczenia człowieka, wyprzedza ten drugi. Otóż wierzący najpierw jest zachęcany, by idąc za Chrystusem, wyrzekł się wszystkiego. I taka jest normalna droga każdego ucznia Chrystusa: motywując swoje działania i wierząc we wspomagające działanie łaski, stara się on oderwać serce od różnego rodzaju dóbr ziemskich i duchowych. W ten ruch oddolny wpisuje się także składany ślub ubóstwa. Na pewnym etapie duchowego rozwoju, osiągając pewien stan pokoju i wolności, człowiek może sądzić, że istotnie jest wolny. Nic bardziej mylnego. To jest właśnie moment, w którym włącza się refleksja o oczyszczeniach biernych, co stanowi centralny punkt nauki Doktora Mistycznego. Ponieważ te zagadnienia zostały już przestudiowane we wszystkich możliwych kierunkach, nie ma potrzeby szczegółowo się tu nimi zajmować. Wystarczy, że streścimy zasadniczą myśl naszego mistyka. Człowiek nie jest w stanie dokonać duchowego ogołocenia za pomocą środków i praktyk, o których sam decyduje. Innymi słowy, nie wystarczy

8 Por. G. Castro, Desnudez espiritual, w: Diccionario de S. Juan de la Cruz, red. E. Pacho, Burgos 2000, s. 399. 
samo oczyszczenie czynne. Inicjatywę musi przejąć Bóg. A kiedy to czyni, daje człowiekowi nowe światło, które wprowadza go w głęboki egzystencjalny kryzys. Wierzącemu ogarniętemu duchową ciemnością oczyszczającą nie pozostaje nic innego, jak tylko całkowicie zdać się na Boga w wierze, nadziei i miłości. Właśnie doktryna dotycząca oczyszczenia duchowych władz przez cnoty teologalne, wyłożona w Drodze na Górę Karmel, znajdzie najwłaściwsze zastosowanie dopiero w nocy biernej zmysłów i ducha. Teraz wierzący nie motywuje już swojego wyrzeczenia nadprzyrodzonymi względami. Te działania już nie skutkują. On po prostu nie znajduje w niczym pociechy: ani w sprawach ziemskich, ani nawet w niebieskich, bo czuje się od nich niejako odcięty. Zostaje przez Boże działanie wprowadzony w taki stan zawieszenia, że nic z rzeczy stworzonych nie może go nasycić, a dobro Najwyższe zdaje się przed nim ukryte.

Św. Paweł mówi, że wobec wspaniałości misterium Chrystusa wszystko uznał za śmieci, a u św. Jana od Krzyża znajdziemy tego wyjaśnienie doświadczalne: wierzący, który całkowicie powierzył swój los Bogu, zaczyna doświadczać nicości wszellkich dóbr przemijających wobec dobra, za jakim jedynie tęskni, to jest dobra osobowej komunii z Bogiem w zjednoczeniu miłości.

W tym świetle można dopiero właściwie odczytać sens ślubu ubóstwa w życiu konsekrowanym: oprócz aspektu czynnej współpracy w dziele duchowego ogołocenia oznaczać on powinien świadome oddanie wszelkiej własności Bogu. Od strony prawnej i moralnej oznacza relację z konkretnymi dobrami materialnymi, jednak jego prawdziwy cel to ubóstwo ducha. Sobór będzie więc przypominał zakonnikom, że mają być ubodzy zarówno w rzeczywistości, jak i w duchu (por. PC 13). Jednak dopiero świadectwo wielkich mistyków pokazuje, że ubóstwo w duchu nie jest tak łatwe do osiagnięcia samym działaniem i decyzją człowieka - co więcej, nie jest możliwe do osiągnięcia tą drogą.

Duchowe ogołocenie to postawa, która powinna towarzyszyć wierzacemu podczas całego procesu uświęcenia, także na najwyższych stopniach duchowego zjednoczenia, jakkolwiek nie ona jest ideałem, celem powołania człowieka. Taka postawa ma swoje źródło w Ewangelii, gdzie Chrystus każe pozostawić wszystko, zaprzeć się siebie i iść za Nim. Św. Jan od Krzyża zakotwicza ogołocenie ucznia w ogołoceniu Chrystusa. Najważniejszy w tym względzie jest rozdział siódmy drugiej księgi Drogi na Górę Karmel. On sam pierwszy realizował to ewangeliczne wymaganie. Pewnym tego znakiem jest już przynależność do zakonu karmelitów bosych (hiszp. descalzos - wyzutych) oraz predykat: Jan od Krzyża. Termin wskazuje na zbliżenie się do ziemi, do ubogich, na uproszczenie wszystkiego. W założeniu Drogi na Górę Karmel czytamy:

Podaje przestrogi i naukę bardzo pożyteczną, tak dla początkujących, jak i dla postępujących, aby umieli otrząsnąć się z rzeczy doczesnych, nie 
obciążać się duchowymi, lecz pozostawać w tym całkowitym ogołoceniu i wolności ducha, jakie są niezbędne do zjednoczenia z Bogiem.

Jeszcze dobitniej mówi nieco dalej w prologu:

Nie będzie to bowiem nauka o ogólnej etyce i kwestiach miłych dla tych osób duchowych, które lubią iść do Boga przez rzeczy słodkie i miłe, lecz będą to istotne i gruntowne wskazania dla wszystkich, którzy zechcą dążyć do przedstawionego tutaj ogołocenia duchowego (DGK, Prolog 8) ${ }^{9}$.

Zjednoczenie z Bogiem jest celem drogi, ogołocenie zaś warunkiem i motorem postępu ${ }^{10}$. Łączy też Święty ogołocenie z miłością: „Miłość nie polega na odczuwaniu wielkich rzeczy, lecz na wielkim ogołoceniu i cierpieniu dla Umitowanego" (Stowa swiatta i mitości, 114). Nie chodzi tu jednak o zwykłe ascetyczne ćwiczenie. Siła potrzebna do sanjuanistycznego ogołocenia pochodzi od Boga, dzięki nieustannie pogłębiającemu się zjednoczeniu z Nim przez wiarę, nadzieję i miłość - cnoty pochodzenia boskiego, udzielone duszy wraz z łaską uświęcającą. Wyraża to dobitnie: intelekt ogołaca się w wierze (DGK II, 24, 8-9), wola ogołaca się w miłości (DGK III, 16,1), a pamięć w działaniu nadziei (DGK III, 3, 6).

Do tych więc cnót nakłonić nam trzeba trzy władze duszy, kształtując każdą z nich w odpowiedniej cnocie, ogołacając je i wprowadzając w ciemność względem tego wszystkiego, co nie jest tymi trzema cnotami. To właśnie, jak to już mówiliśmy, nazywa się czynną nocą ducha (DGK II, $6,6)^{11}$.

W nocy ciemnej proces uświęcenia dokonuje się w oparciu o te same zasady, czyli osiągnięcie całkowitego ogołocenia dla miłości, zmienia się jednak radykalnie sposób dochodzenia do niego: teraz jest to boskie działanie i dokonuje się w sposób bierny ${ }^{12}$.

9 „By dojść do tego celu, po tej drodze trzeba zawsze iść naprzód, trzeba postępować, wyzbywając się pragnień (...). Jeżeli się nie wyzbędzie wszystkiego, nie dojdzie się do celu” (DGK I, 11, 6); „By szukać Boga, trzeba mieć serce ogołocone, mężne i wolne od wszelkiego zła i od wszelkiego dobra, które nie jest samym Bogiem. Mówi więc dusza w tym i w następnych wierszach o wolności i odwadze, jaką musi mieć, szukając Boga" (PD 3, 5)

10 Por. G. Castro, Desnudez espiritual, s. 404.

11 Zob. także DGK II, 6, 7.

12 Por. G. CAstro, Desnudez espiritual, s. 405. „Dlatego, by dojść do niego [zjednoczenia], musi dusza wejść w tę drugą noc ducha, w której część zmysłowa i duchowa oczyszcza się doskonale z wszystkich pojmowań i upodobań. Wtedy dopiero będzie mogła postępować przez ciemną i czystą wiarę, która jest właściwym i odpowiednim środkiem złączenia się z Bogiem" (NC II, $2,5)$. 
W nocy biernej ogołocenie staje się synonimem kontemplacji wlanej. Przez nią bowiem Bóg oczyszcza duszę z wszelkich przywiązań. Ogołocenie kojarzy się ze zdejmowaniem ubrania. W tej nocy chodzi o coś o wiele głębszego, dotykającego dna duszy; chodzi o wewnętrzną przemianę, do czego zwylkłe ogołocenie nie wystarczy. To, co się teraz musi dokonać, nie da się wyrazić słowem „ogołocić”, dlatego mamy inne określenia: niweczyć, rozbić, roztrząsnąć, zmiażdżyć, obalić, być trawionym przez dziką bestię ${ }^{13}$.

$\mathrm{Na}$ dalszych etapach zjednoczenia „ogołocenie” oznacza coś pozytywnego, mianowicie boską komunikację bardziej bezpośrednią w czystej wierze, prawie bez udziału pośredników: „z ust do ust” - w nawiązaniu do rozmowy Boga z Mojżeszem ${ }^{14}$ :

(...) w tym wzniosłym stanie zjednoczenia, o którym mówimy, Bóg nie udziela się duszy za pośrednictwem jakiejś zasłony widzenia wyobrażeniowego czy podobieństwa lub kształtu (nie może nawet ich mieć), lecz bezpośrednio, $z$ ust do ust. Czysta i ogołocona Istota Boża, która jest jakby Bożymi ustami miłości, łączy się z czystą i ogołoconą istotą duszy, będącej jej ustami miłości ku Bogu (DGK II, 16, 9).

Bóg udziela się wierzącemu w sposób nadzwyczajny bez pośrednictwa zmysłów.

W podsumowaniu można powiedzieć, że ubóstwo jest pojęciem o charakterze moralnym, ściśle związanym $z$ doskonałością, $z$ wejściem na jej szczyt ${ }^{15}$. Od strony negatywnej wiąże się z przywiązaniem do wszelkiego rodzaju dóbr i z koniecznością oderwania od nich serca; wiąże się także z ludzkim sposobem

13 „Trzeci rodzaj utrapienia i zmartwienia, jakie tu dusza odczuwa, pochodzi z dwóch ostateczności, które się tu łączą razem, tzn. boski ej i ludzki j. Czynnikiem boskim jest kontem placja oc zy s zczając a, aczynnikiem ludzkim jest podmiot samej duszy. Ten czynnik boski napełnia ją sobą, aby zniweczyć jej cierpienia, aby ją odnowić i uczynić ją bardziej boską. Dlatego pozbawia ją odczuć habitualnych i właściwości starego człowieka, z którymi dusza jest jeszcze ciągle złączona, zespolona i do nich podobna. Działanie to tak rozbija i roztrząsa samą substancję duszy, tak ją zanurza w głębokiej i gęstej ciemności, że dusza czuje się tu całkowicie zmiażdżona i obalona na twarz. Widok jej własnej nędzy jest dla niej jakby okrutną śmiercią duchową. Czuje się, jakby była połknięta przez jakiegoś potwora, i odczuwa cierpienia podobne do tych, jakie cierpiał Jonasz w brzuchu bestii morskiej (Jon 2, 1) Musi bowiem wejść w ten grób ciemnej śmierci, aby następnie mogła dojść do czekającego ja [duchowego] zmartwychwstania" (NC II, 6, 1).

14 Por. G. Castro, Desnudez espiritual, s. 407.

15 „Dusza pragnąca wstąpić na górę doskonałości, by tam obcować z Bogiem, nie tyllko musi się wyrzec wszystkich rzeczy i zostawić je na dole, lecz i pożądania, które są jak zwierzęta, musi poskromić i nie pozwalać im zbliżyć się do tej góry, tzn. rozkoszować się innymi rzeczami, które nie są Bogiem" (DGK I, 5, 6). 
obcowania z Bogiem; od strony pozytywnej jest efektem Bożego działania upodabniającego wierzącego do ubogiego Chrystusa ${ }^{16}$.

Jezus mówi w Ewangelii o szczęściu, które niesie z sobą ubóstwo ducha. To szczęście jest udziałem doktorów Karmelu.

\subsection{Czystość}

W pismach św. Teresy niewiele znajdziemy wzmianek o czystości konselkrowanej, poza sporadyczną zachętą, by ją pielęgnować, i wspomnianej aluzji do trzech rad ewangelicznych na początku Drogi doskonałości. Pisze dużo o czystości miłości jako o jednym $z$ podstawowych wymogów modlitwy przyjaźni z Chrystusem (D 4-7), ale wiadomo, że to zagadnienie nie jest ściśle związane ze ślubem czystości ${ }^{17}$.

W tej sytuacji, podobnie jak w przypadku posłuszeństwa i ubóstwa, potrzebne jest spojrzenie $z$ punktu widzenia teologicznego i mistycznego, a w tej optyce znajdziemy bogate nauczanie dotyczące relacji oblubieńczej, który to symbol narzuca się Teresie z kobiecą naturalnością. Ucieka się do niego najpierw, by wyrazić osobiste doświadczenie mistyczne, a następnie by ukazać najwyższy pułap mistycznego rozwoju duchowego ważny dla wszystkich wierzących.

Czystość staje się wymiarem oblubieńczym całego życia, a to oznacza otwartość najpierw na Boga, a potem na ludzi. Taka postawa wynika ze zrozumienia Bożego daru: to On uczynił ją swoją i uzdolnił do miłowania tak, jak On miłuje ${ }^{18}$. Do mniszek pisze, że są oblubienicami Chrystusa (D 22,7) i powinny zabiegać o Jego względy o wiele bardziej niż kobiety zamężne o względy mężów (D 11,3; D 26, 4). Kiedy przypada jakaś uroczystość profesji lub jej rocznica, św. Teresa tworzy okolicznościowe poezje. W Dziełach ${ }^{19}$ jest ich zbiór w liczbie dziewięciu. Mówi w nich o casamiento sagrado - świętym zamążpójściu (P 23), o Chrystusie jako Esposo-Mężu, który obsypuje oblubienicę hojnymi darami (np. P 21, P 24), desposado - poślubionym (P 23). Taka relacja wymaga oczywiście czystej miłości (np. Ż 28, 10).

Motyw czystości to, naturalnie, miłość do Chrystusa i służba Ewangelii. Jej czystość jest płodna, bo wolna i świadoma ${ }^{20}$. Swoje cechy i bogactwo przejmuje od Chrystusa, przede wszystkim drogą Eucharystii, która staje się dla niej celebrowaniem jej oblubieńczej relacji z Nim: im bardziej czuje się zjednoczona z Chry-

16 Por. G. Castro, Desnudez espiritual, s. 407-408

17 Por. F. Malax, Consejos evangelicos, s. 162.

18 Por. L. BorielLo, Giovanni della Croce. Temi maggiori di spiritualità teresina, Roma Morena 2005, s. 138.

19 Por. Santa Teresa de Jesús, Obras completas, oprac. E. Llamas, T. Egido, Madrid 1984³ , s. $1196-$ -1205 .

20 Por. L. Boriello, Giovanni della Croce, s. 139. 
stusem, tym bardziej otwiera się na innych ${ }^{21}$. Z tego zjednoczenia wynika płodne macierzyństwo. Dzisiaj w Karmelu zwracamy się do niej jako do Matki.

W przypadku św. Teresy od Dzieciątka Jezus sytuacja jest podobna. Wystarczy tu przytoczyć jeden wymowny przykład. Opisuje ona:

Osiem dni po mojej welacji odbył się ślub Joanny [ Joanna Guérin, jej kuzynka]. Mówiłaś mi, moja droga Matko, że jej przylład winien mnie pouczyć, ile delikatności powinna okazać oblubienica swojemu Oblubieńcowi. Nie do zniesienia była dla mnie myśl, bym mogła mniej uczynić dla mego ukochanego Jezusa niż Joanna dla Franciszka (...). Zabawiłam się ułożeniem sobie zaproszenia ślubnego na wzór jej zaproszenia ${ }^{22}$.

Tu następuje znane zaproszenie na ślub Teresy z Królem królów. Oczywiście należałoby tu poczynić pewne zastrzeżenia, a nawet wskazać niebezpieczeństwa tej analogii, jednak chodzi nam jedynie o kierunek poszukiwań sensu konsekrowanej czystości i o perspektywę, w jakiej ją przeżywali nasi doktorzy.

Św. Jan od Krzyża poza jednym czy drugim przypadkiem praktycznie nie używa terminu „czystość” - castidad - na oznaczenie ślubowanej rady czystości w życiu konsekrowanym. Znajdziemy natomiast dwa inne - pareza i limpieza-które również tłumaczymy jako czystość. On czyni to całkiem świadomie, by było oczywiste, iż nie ma tu na myśli tylko zakonników, ale wszystkich wierzących, i że chodzi mu o czystość miłości ${ }^{23}$. Tak więc od strony terminu i ślubowanej czystości nie rozwiniemy tematu. Trzeba ustawić się w perspektywie, w jakiej Święty pisze swoje dzieła, i również szukać rozwiązania po linii mistycznego zjednoczenia z Bogiem w miłości ${ }^{24}$.

Jak wielu wcześniejszych i współczesnych mistyków, św. Jan od Krzyża sięga po symbol oblubieńczy, by wyrazić relację miłości pomiędzy Bogiem i człowiekiem, zawsze w nawiązaniu do Pieśni nad pieśniami. Najważniejsze dwa hiszpańskie terminy wyrażające tę oblubieńczą relację to desposorio - zaręczyny, oraz matrimonio - zaślubiny małżeńskie. Cały ten proces także może być nazwany zaślubinami. W tej chwili nie interesują nas zależności terminologiczne i różnice pomiędzy zaręczynami a zaślubinami, ale cały proces zjednoczenia w miłości obejmujący czas jednych i drugich ${ }^{25}$. Reprezentatywny w tym względzie telsst

21 Por tamże

22 Sw. Teresa od DzieciątKa Jezus, Dzieje duszy, Kraków 1984, rkps A, rozdz. 8.

23 Por. E. Renedo, Pareza, w: Diccionario de S. Juan de la Cruz, s. 1219.

24 Por. E. PACHo, Desposorio espiritual, w: Diccionario de S. Juan de la Cruz, s. 408-422.

25 Zob. szczegóły tamże, s. 408-411. Autor wyróżnia trzy znaczenia desposorio: relację pomiędzy Bogiem a stworzeniami, miłosne zjednoczenie pomiędzy Chrystusem a wszystkimi ludźmi oraz szczególny stan duchowy poprzedzający mistyczne małżeństwo (s. 411). Zob. także wyczerpujące studium na temat obydwu tych stanów w: O.R. STokŁosa, Wzrastać w mitości 
znajdziemy w komentarzu do Pieśni duchowej. Jedne zaślubiny dokonały się na krzyżu, a patrząc od strony człowieka, na chrzcie świętym; drugie dokonują się stopniowo na drodze osiągania doskonałej miłości (PD 23, 6).

W tej sytuacji oczyszczanie serca, o którym wspomnieliśmy przy okazji omawiania rady ubóstwa, automatycznie odnosi się do czystości konsekrowanej, gdyż proces jest jeden i zaślubiny są jedne. Można by wysunąć obiekcję, że nie poruszamy głównego tematu, bo czystość miłości wymagana jest absolutnie od wszystkich wierzących. Jeżeli jednak zgłębimy znaczenie ślubowanej czystości konsekrowanej w oparciu o naukę Kościoła, okaże się, że ma ona sens oczywiście chrystologiczny, ale również eklezjalny ${ }^{26}$. Ma być mianowicie znakiem dla wszystkich wierzących, że ich miłość musi być ukierunkowana na Boga i w Nim dopełniona; że miłość Boga ponad wszystko jest zadaniem wszystkich, niezależnie od stanu życia. Mężczyzna nie jest stworzony dla kobiety, a kobieta dla mężczyzny, ale Bóg wszystkich powołuje do siebie. Miłość małżeńska nie może być zamknięta w relacji jedynie poziomej, bo wówczas nie zdoła być czysta.

\section{ZAKOŃCZENIE}

W punkcie wyjścia jesteśmy skłonni twierdzić, że nauka doktorów Karmelu o radach ewangelicznych jest przestarzała i idzie torem myśli przedsoborowej, która została całkowicie przepracowana w ciągu ostatnich pięćdziesięciu lat; po nieco dokładniejszej analizie ich myśli pod tym kątem musimy stwierdzić, że to właśnie dzięki takim osobom i takiemu mistycznemu doświadczeniu możliwe stało się przeniesienie refleksji o radach ewangelicznych z poziomu czysto jurydycznego i moralnego na głęboki poziom mistyczny, na którym dopiero ujawnia się prawdziwy ich sens i zasięg.

Bożej. Zagadnienie rozwoju mitości Bożej w cztowieku wedtug św. Jana od Krzyża, Kraków 2011, s. 333-444.

26 Por. J.W. GogolA, Rady ewangeliczne. Teologia, praktyka, formacja, s. 261-369. 


\title{
RIASSUNTO
}

\author{
Jerzy W. GoGolA \\ I consigli evangelici secondo $i$ Dottori del Carmelo
}

All'inizio ci poniamo la domanda sull'opportunità di uno studio dei consigli evangelici sulla base di autori vissuti qualche secolo fa, dato che la teologia della vita consacrata, in questo nostro tempo, ha subito un grande cambiamento. L'analisi del pensiero dei nostri Dottori al riguardo, ci permette di ricevere una risposta adeguata a questa domanda.

La struttura della nostra riflessione è la seguente: dopo uno sguardo generale ai consigli evangelici negli scritti dei nostri Santi, si passerà ad uno studio più dettagliato di ciascuno di essi.

Inizialmente siamo inclini ad affermare che la dottrina dei Dottori del Carmelo intorno ai consigli evangelici è obsoleta e segue il cammino della dottrina preconciliare, che è stata quasi completamente rielaborata negli ultimi cinquanta anni. Però, alla fine di un'analisi un po' più approfondita, siamo costretti a concludere che, proprio grazie a tali persone ed alla loro esperienza mistica, è stato possibile spostare la riflessione circa i consigli evangelici da un livello puramente morale e giuridico ad un livello profondamente mistico, che solo rivela il loro vero significato e la portata.

Słowa klucze: rady ewangeliczne, doktorzy Karmelu, życie konsekrowane, doświadczenie mistyczne

Parole chiavi: consigli evangelici, Dottori del Carmelo, vita consacrata, esperienza mistica 